\title{
Method of Application of Uniconazol Affects Vegetative Growth of Pecan
}

\author{
Charles J. Graham ${ }^{1}$ and J. Benton Storey ${ }^{2}$ \\ Department of Horticultural Science, Texas A\&M University, College Station, \\ TX 77843-2133
}

Additional index words. Carya illinoensis, growth regulator, growth inhibitor, nutrition, shoot length, trunk diameter, viviparity

\begin{abstract}
Pollarded 'Wichita' pecan [Carya illinoensis (Wang) K. Koch] trees received 2 g uniconazol (UCZ) per tree using four application methods (trunk band, canopy soil injection, crown soil injection, and crown drench). All application methods increased trunk diameter but reduced shoot length, number of lateral shoots per terminal, nodes per terminal, internode length, and leaflets per compound leaf. Only the crown drench reduced leaf area. Area and dry weight per leaflet, and leaflet chlorophyll concentration were not affected by UCZ application. Effectiveness in growth reduction, as assessed by shoot elongation, was crown soil drench > crown soil injection > canopy soil injection > trunk band > control. All application methods increased viviparity. However, total yield per tree, nut size, and percentage of kernel were not affected. Chemical name used: (E)-1-(p-chlorophenyl)-4,4-dimethyl-2-(1,2,4-triazol-1-yl)-1-penten-3-ol (uniconazol).
\end{abstract}

The vigorous growth habit of pecan limits efficient pest control and use of orchard space, necessitates expensive spray equipment, and contributes to low yield efficiency. Yields are often greater in high density than in lower density orchards in the early years, but decline as crowding occurs (Malstrom et al., 1978; Malstrom and Haller, 1979). Hedging or alternate tree removal is typically used to alleviate this problem (Worley, 1977). Dormant pruning by hedging or pollarding removes vegetative growing points, resulting in a concentration of reserves in fewer vegetative growing points upon the release of dormancy. Thus, excessive vegetative growth and reduced flowering often result. The time necessary for the trees to return to normal production is dependent on the precocity of the cultivar, ranging from 2 years for 'Western' (Malstrom et al., 1982) to 5 years for 'Stuart' and 'Schley' (Malstrom et al., 1978).

A chemical method to control pecan tree size could replace or supplement certain cultural methods of control. The use of growth regulating chemicals in the late 1960s and early 1970s was unsuccessful because of undesirable effects on nut quality or inadequate control of vegetative growth (Malstrom and

Received for publication 10 Aug. 1999. Accepted for publication 6Mar. 2000. Contribution from the Texas Agriculture Experiment Station. Appreciation is extended to the Valent Chemical Co., (Research Park, Ill.) for donation of the uniconazol. Use of trade names does not imply endorsement of the products named nor criticism of similar ones not named. The cost of publishing this paper was defrayed in part by the payment of page charges. Under postal regulations, this paper therefore must be hereby marked advertisement solely to indicate this fact.

${ }^{1}$ Associate Professor. Current address is Calhoun Research Station, Louisiana State University Agricultural Center, P.O. Box 539, Calhoun, LA 71225. E-mail address: cjgraham@agctr.lsu.edu ${ }^{2}$ Professor of Horticulture.
McMeans, 1978). A major development in the late 1970s was the production of a new family of triazole growth regulators that provided long-lasting control of vegetative growth without harmful effects on cropping (Davis et al., 1988). Triazoles may provide a solution to the problem of excessive crowding in pecan orchards if they are ever registered for use.

Paclobutrazol [ $( \pm)-\left(\mathrm{R}^{*}, \mathrm{R}^{*}\right)-\beta$ - $[(4$-chlorophenyl)methyl)- $\alpha$-(1,1-dimethyl)- $1 H-1,2,4-$ triazol-1-ethanol (PBZ)], a triazole compound, has been effective when applied to apple [Malus $\times$ domestica (Borkh.)] and peach [Prunus persica (L.) Batsch] trees (Lever, 1986). It has been applied using soil surface application, soil surface banding, soil injection, trunk crown drench, subsoil banding, tree injection, and trunk bark painting (Davis and Curry, 1991). All methods reportedly reduce growth. The application method chosen for triazoles appears to be dependent on orchard conditions and plant species. Generally, foliar sprays are more effective than soil treatments on pome fruit, while soil and foliar applications are effective on stone fruit (Lever, 1986).

Uniconazol (UCZ), a triazole compound related to PBZ, when applied as a soil treatment to 'Cheyenne' and 'Desirable' pecan trees at rates of 132,264 , and 588 $\mathrm{mmol} \cdot \mathrm{cm}^{2}$ trunk cross-sectional area (TCSA), reduced shoot growth, leaf area, and number of leaves for 3 years after application (Wood, 1988c). Application of PBZ reduced growth of both pecan seedlings and large trees (Marquard, 1985; Wood, 1984, 1988a). With the above exception (Wood, 1988c), no data are available for the comparison of triazole treatment application methods in nut crop production. Therefore, this study assessed the efficacy of several methods of UCZ application on the vegetative and reproductive growth of severely pruned 'Wichita' pecan trees.
Treatment conditions. Ten-year-old 'Wichita' trees (Perry Pecan Orchard, Maverick County, Texas) spaced $9.1 \mathrm{~m}$ apart in a diagonal system, were used in this study. The trees were growing on a Laredo silty clay loam (fine-silty, mixed, hyperthermic, Fluventic Haplustoll) and flood irrigated as needed to maintain proper soil moisture. Prior to chemical application in 1987, the scaffold limbs were pollarded to within $1 \mathrm{~m}$ of the trunk and the trees were topped at a height of $3 \mathrm{~m}$. The experimental design was a randomized complete-block with four single-tree replications and four treatments (trunk band, canopy soil injection, crown soil injection, crown soil drench, and a control).

Chemical applications were made on 10 Mar. 1987 using $2 \mathrm{~g} \mathrm{UCZ}$ per tree. The trunk band was applied to the bark $1 \mathrm{~m}$ above the soil-trunk interface in a total volume of 30-50 $\mathrm{mL}$ of diesel : toluene $(70: 30 \mathrm{v} / \mathrm{v})$ solution as a carrier. The canopy soil injection was applied in $38 \mathrm{~L}$ water at a depth of $25 \mathrm{~cm}$ in eight injection sites located equidistant around the canopy dripline of each tree. The crown soil injection was applied in $1.5 \mathrm{~L}$ water at a $12-\mathrm{cm}$ depth at six injection sites located $45 \mathrm{~cm}$ from the trunk equidistant around the tree. The crown drench was applied in $1 \mathrm{~L}$ water at the soil-trunk interface of each tree.

Vegetative growth. Tree trunks were marked at $1 \mathrm{~m}$ above the soil surface at the initiation of the experiment, trunk diameter was measured while the trees were dormant in 1987, 1988, and 1989, and the TCSA was calculated. Ten current-season shoots from the midcrown of each tree were tagged and the terminal growth (defined as shoot length) was measured on 13 July, 16 Aug., and 17 Oct. 1987, and 30 Jan. 1988. Only the dominant terminal shoot was measured on the first three dates. Terminal growth, lateral growth, and number of laterals per 1-year-old branch were recorded at the end of the 1987 growing season and averaged for each tree. In addition to the growth parameters measured in 1987, the numbers of nodes per terminal and lateral were determined at the end of the 1988 growing season. Only terminal growth and nodes per terminal were measured at the end of the 1989 growing season. From these data the internode length was calculated for 1988 and 1989. Leaf size was determined by collecting the middle leaf from 10 randomly selected terminals at midcanopy height, then measuring area in July 1987 and 1988 using a LI-COR area meter (LICOR-3000; LI-COR, Lincoln, Nebr.). In 1988, the number of leaflets per compound leaf and total area per leaf were recorded, and the leaves were dried $24 \mathrm{~h}$ at $60^{\circ} \mathrm{C}$ and weighed. Prior to drying, chlorophyll concentrations were measured with the SPAD 501 (Minolta Corp., Ramsey, N.J.). Chlorophyll was extracted in $80 \%$ acetone and determined by spectrophotometry to develop a standard curve. Regression analysis was used to calculate the chlorophyll concentration of experimental trees based upon the SPAD 501 readings (Yadava, 1986). 
Mineral concentration. The middle pair of leaflets from the middle leaf on currentseason's growth were collected in 1987 and 1988 , washed according to the procedure of Smith and Storey (1976), dried at $60^{\circ} \mathrm{C}$, and ground in a Wiley mill to pass a 40-mesh screen. About $250 \mathrm{mg}$ of tissue were wetdigested using a $\mathrm{H}_{2} \mathrm{SO}_{4}-\mathrm{H}_{2} \mathrm{O}_{2}$ solution with $\mathrm{Se}$ and $\mathrm{Li}_{2} \mathrm{SO}_{4}$ as a catalyst (Storey and Sistrunk, 1987). Total N was determined using a Technicon Autoanalyzer II (Technicon Instruments, Tarrytown, N.Y.). Determination of $\mathrm{P}, \mathrm{K}, \mathrm{Mg}, \mathrm{Ca}, \mathrm{Na}, \mathrm{Cu}, \mathrm{Fe}, \mathrm{Mn}, \mathrm{Mo}$, and $\mathrm{Zn}$ was by inductively coupled plasma emission spectrometry (Applied Research Laboratories, Sunland, Calif.).

Nut yield and quality. The yield of each tree was determined by hand-harvesting the entire crop or estimating the yield using the quadrant method reported by Worley and Smith (1984). Ten-nut subsamples were used to determine nut size, percentage of kernel, and percentage of viviparity.

Statistical analysis. Data were analyzed using SAS (SAS Institute, Cary, N.C.) and means were separated by Duncan's multiple range test.

\section{Results and Discussion}

Influence of uniconazole on vegetative growth. In 1987-88, only the crown soil injection increased TCSA $\left(20.9 \mathrm{~cm}^{2}\right.$ vs. $8.25 \mathrm{~cm}^{2}$ for the control), and no differences in trunk growth were noted in 1989 (data not shown). Mika (1986) reported that dormant pruning increased the growth of new shoots, but decreased trunk expansion and root growth, because reserve and current assimilates were preferentially allocated to a smaller number of rapidly growing branches. In our study, the increased trunk growth of trees receiving a crown soil injection of UCZ was presumably the result of increased assimilates available for secondary (trunk) growth at the expense of shoot growth.

Terminal shoot growth was reduced in all 3 years following application of UCZ (Table 1). On 13 July of the year of application, trunk band, crown soil injection, and crown drench applications had reduced growth. By 16 Aug., all four application methods had reduced terminal length, with the crown soil drench treatment being the most effective. Only minimal shoot growth occurred after Aug. 1987. All but the canopy soil injection had retarded terminal growth by the end of the 1988 growing season. The crown soil injection and the crown drench treatments had the strongest carry-over effects. At the end of the study (3 years following UCZ application), shoot growth was markedly lower in all UCZ treatments. By this time, the growth-inhibiting effects of the crown soil injection and drench treatments persisted, even to a greater extent than in 1987 , reducing shoot extension by $\approx 70 \%$ to $80 \%$. However, the strongest growth inhibition by these treatments appeared to occur in 1988, the second season following application (78\% to $85 \%$ below control, respectively).

Table 1. Effects of method of application of uniconazol in Spring 1987 on vegetative growth of 'Wichita' pecan trees.

\begin{tabular}{|c|c|c|c|c|c|}
\hline \multirow[b]{2}{*}{ Date/year } & \multicolumn{5}{|c|}{ Application method } \\
\hline & Control & Canopy soil injection & Trunk band & Crown soil injection & Crown drench \\
\hline \multicolumn{6}{|c|}{ Length of terminal shoots $(\mathrm{cm})$} \\
\hline 13 July 1987 & $175 \mathrm{a}^{\mathrm{z}}$ & $155 \mathrm{ab}$ & $147 \mathrm{~b}$ & $149 \mathrm{~b}$ & $136 \mathrm{~b}$ \\
\hline 16 July 1987 & $208 \mathrm{a}$ & $164 \mathrm{~b}$ & $164 \mathrm{~b}$ & $155 \mathrm{bc}$ & $137 \mathrm{c}$ \\
\hline 17 Oct. 1987 & $226 \mathrm{a}$ & $167 \mathrm{~b}$ & $169 \mathrm{~b}$ & $155 \mathrm{bc}$ & $137 \mathrm{c}$ \\
\hline Dec. 1987 & $226 \mathrm{a}$ & $171 \mathrm{~b}$ & $173 \mathrm{~b}$ & $156 \mathrm{bc}$ & $138 \mathrm{c}$ \\
\hline Dec. 1988 & $166 \mathrm{a}$ & $72 \mathrm{ab}$ & $92 \mathrm{~b}$ & $36 \mathrm{~cd}$ & $25 \mathrm{~d}$ \\
\hline Dec. 1989 & $67 \mathrm{a}$ & $52 \mathrm{a}$ & $48 \mathrm{a}$ & $21 \mathrm{~b}$ & $13 \mathrm{~b}$ \\
\hline \multicolumn{6}{|c|}{ Number of lateral shoots per terminal } \\
\hline 1987 & $5 \mathrm{a}$ & $5 \mathrm{a}$ & $5 \mathrm{a}$ & $1 \mathrm{~b}$ & $1 \mathrm{~b}$ \\
\hline 1988 & $8 \mathrm{a}$ & $3 \mathrm{~b}$ & $4 \mathrm{~b}$ & $1 \mathrm{~b}$ & $1 \mathrm{~b}$ \\
\hline \multicolumn{6}{|c|}{ Total lateral shoot growth per terminal $(\mathrm{cm})$} \\
\hline 1987 & $245 \mathrm{a}$ & $132 \mathrm{a}$ & $119 \mathrm{a}$ & $88 \mathrm{a}$ & $53 \mathrm{a}$ \\
\hline 1988 & $37 \mathrm{a}$ & $6 \mathrm{~b}$ & $8 \mathrm{~b}$ & $1 \mathrm{~b}$ & $1 \mathrm{~b}$ \\
\hline \multicolumn{6}{|c|}{ Total lateral + terminal shoot growth per terminal $(\mathrm{cm})$} \\
\hline 1987 & $471 \mathrm{a}$ & $303 \mathrm{~b}$ & $291 \mathrm{~b}$ & $243 \mathrm{bc}$ & $190 \mathrm{c}$ \\
\hline 1988 & $203 \mathrm{a}$ & $77 \mathrm{bc}$ & $100 \mathrm{~b}$ & $37 \mathrm{~cd}$ & $26 \mathrm{~d}$ \\
\hline \multicolumn{6}{|c|}{ Nodes per terminal shoots } \\
\hline 1988 & 36 ay & $25 \mathrm{bc}$ & $31 \mathrm{ab}$ & $25 \mathrm{bc}$ & $22 \mathrm{c}$ \\
\hline 1989 & $23 \mathrm{a}$ & $23 \mathrm{a}$ & $21 \mathrm{ab}$ & $20 \mathrm{~b}$ & $16 \mathrm{c}$ \\
\hline \multicolumn{6}{|c|}{ Terminal internode length $(\mathrm{cm})$} \\
\hline 1988 & $4.6 \mathrm{a}$ & $2.7 \mathrm{~b}$ & $2.9 \mathrm{~b}$ & $1.5 \mathrm{c}$ & $1.1 \mathrm{c}$ \\
\hline 1989 & $2.9 \mathrm{a}$ & $2.5 \mathrm{a}$ & $2.1 \mathrm{a}$ & $1.0 \mathrm{~b}$ & $0.8 \mathrm{~b}$ \\
\hline \multicolumn{6}{|c|}{ Leaf growth 1988} \\
\hline Leaflets/leaf & $19 \mathrm{a}$ & $16 \mathrm{~b}$ & $16 \mathrm{~b}$ & $15 \mathrm{bc}$ & $14 \mathrm{c}$ \\
\hline Area/leaf $\left(\mathrm{cm}^{2}\right)$ & $594 \mathrm{a}$ & $498 \mathrm{ab}$ & $586 \mathrm{a}$ & $470 \mathrm{ab}$ & $419 b$ \\
\hline
\end{tabular}

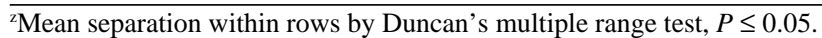

The variation in growth reduction among application methods (Table 1) may be a result of the concentration of the chemical used and the relative absorbing surface of the tree (i.e., roots or trunk) exposed to that concentration. Comparing the soil treatments, the crown drench may have exerted a greater impact on the tree's shoot growth because of its higher effective concentration (less water was needed to make the application), and because of its direct contact with the roots or crown. The canopy soil injection may expose a greater portion of the actively absorbing "feeder" root surface of the tree to UCZ (eight injection sites), but at about a 40-fold lower concentration for a given quantity of UCZ applied in our experimental conditions. Broadcast soil sprays may provide higher levels of growth retardation and increase treatment uniformity when adequate leaching into the root zone occurs, since more roots would come in contact with the chemical than would be the case with injections (Wood, 1988a). Trunk banding may be less effective because the bark impedes movement of the chemical into the secondary xylem tissue of the tree. Thus, the level of exposure along the root-to-shoot xylem pathway parallels the degree of growth retardation by the various treatments.

Application of UCZ did not reduce the number of lateral shoots per terminal or total lateral shoot extension until the second growing season, with all application methods being equally effective (Table 1). However, because of preferential growth suppression of the terminal shoot, all application methods reduced total current-year shoot elongation during the same season of treatment. This effect persisted through the second growing season, and, again, crown-applied UCZ was the most effective in growth control.

All application methods, except the trunk band, reduced the number of nodes per terminal in 1988, but only the crown applications (injection and drench) reduced node number in 1989 (Table 1). Over the 2-year period, internode length paralleled node number in the terminal shoot. Because of reductions in both node number and internode length, our findings suggest that the suppression of vegetative growth in pecan caused by UCZ results from its combined regulation of cell division and elongation. These findings agree with those of Wareing and Phillips (1970).

None of the application methods influenced the average area of the midleaflets or average leaflet dry weight in 1987 or 1988 (data not shown). However, by 1988, all application methods, especially the crown drench and crown injection treatments, had reduced the number of leaflets per compound leaf. Although there was a trend for reduced area per leaf for all UCZ treatments, only the effect of the crown drench treatment was statistically significant.

Our data agree with previous reports of pecan tree leaf growth following triazole application. Wood (1986) applied paclobutrazol, flurprimidol ( $\alpha$-(1-methylethyl)- $\alpha$-[4(trifluoromethoxy)phenyl]-5-pyrimidinemethanol), and uniconazol as a basal drench to 4-year-old 'Cheyenne' and 'Desirable' trees. A single application of any of the three chemicals reduced shoot growth, leaf area, and the number of leaves per shoot. Wood (1988a) treated 75-year-old 'Stuart' trees with PBZ at rates of $0,50,100$, and $200 \mathrm{mg} \cdot \mathrm{cm}^{2}$ trunk diameter using either trunk injection, or a 
spray to the orchard floor at rates of $0,19,38$ and $76 \mathrm{~g}$ per tree. Both treatment methods reduced area per leaf and total leaf area per shoot for as long as 4 years after application, even though the number of leaves per shoot was not influenced the season after treatment. Similar results have been obtained with young greenhouse-grown pecan seedlings (Wood, 1984).

None of the UCZ application methods used in our experiment influenced midleaflet chlorophyll concentration (data not shown). This contradicts previous studies in apple (Steffans and Wang, 1986) and pecan (Wood, 1984) that reported increases in leaf chlorophyll concentrations following treatment with PBZ. These studies were performed on young seedlings that may have been more PBZsensitive because of a much smaller pool for dilution than in a larger tree, thereby exposing the leaves to a higher concentration of chemical.

Effect of uniconazole on leaf nutrient concentration. The influence of UCZ application method on leaflet elemental concentrations was highly variable, with no consistent increase or decrease (data not shown). All of the nutrient levels fell within the range considered to be adequate for pecan growth and yield (O'Barr, 1977) and were similar to the concentrations measured by Sparks and Madden (1977) for individual genotypes. Fluctuations appeared to be more prominent in the metallic cations, especially the micronutrients $\mathrm{Cu}$ and Mn. Few published reports indicate a large change in the nutrient concentrations of woody species following application of UCZ.

Nut yield and quality. The severely pollarded 'Wichita' trees were entirely vegetative the first 2 years following application of UCZ, but they produced a light crop the third year. Yield per tree, nut size, and percentage of kernel were not affected by UCZ (data not shown). However, UCZ appeared to increase rates of viviparity, but the effect was significant only for the crown soil drench (25\% vs. $0 \%$, respectively, for UCZ treatment vs. control).

Studies involving the influence of PBZ on the yield of pecan trees are conflicting, with both increases and decreases reported, depending on cultivar, age, application method, and the time elapsed after application. In
Wood's (1988a) study of 75-year-old 'Stuart', in-shell yield was not affected by trunk injections the first 2 years after treatment, but was reduced by high PBZ application rates the third and fourth years after treatment. Conversely, yield increased in the second year following soil spray application. In young PBZ-treated pecan trees $(\approx 10$ years old $)$, yields may increase, decrease, or remain unchanged, depending on cultivar and time after application (Wood, 1988b). Thus, further research is needed to reconcile these apparent sources of yield variation and actual effects of triazoles on yield.

\section{Conclusions}

The application of UCZ using canopy soil injections, trunk bands, crown soil injections, or crown drenches suppressed vegetative growth, but crown soil injection and drench applications were generally the most effective methods. The crown drench technique has the advantage of not requiring the use of specialized equipment (i.e., soil or trunk injector) or use of organic chemicals as a carrier (trunk band), that would be necessary for the other methods tested. This research demonstrates the wide responses that can occur following the use of different application methods. Further experimentation is necessary to determine the interactions among application frequency, rate, and method on long-term growth and production of pecan. The interplay of nutrition, growth regulator applications, irrigation, pest infestations, and other factors must be considered in deriving predictable and desirable methods. Residue analyses of soil and marketable product still await quantification before UCZ can be applied to commercial systems.

\section{Literature Cited}

Davis, T.D. and E.A. Curry. 1991. Chemical regulation of vegetative growth. Crit. Rev. Plant Sci. 10:151-188.

Davis, T.D., G.L. Steffans, and N. Sankhla. 1988. Triazole plant growth regulators. Hort. Rev. 10:63-105.

Lever, B.K. 1986. 'Cultar'-A technical overview. Acta Hort. 179:459.

Malstrom, H.L. and R.L. Haller. 1979. Consequences of hedge pruning pecan trees. Texas Pecan Growers Assn. Proc. 58:52-56.

Malstrom, H.L., G. Horst, and M. Kilby. 1978.
Necessity of pruning crowded orchards. Texas Pecan Growers Assn. Proc. 57:38-39.

Malstrom, H.L. and J.L. McMeans. 1978. Chemical pruning young pecan trees. Pecan Quart. 12(1):23-24, 26, 28.

Malstrom, H.L., T.D. Riley, and J.R. Jones. 1982. Continuous hedge pruning affects light penetration, and nut production of 'Western' pecan trees. Pecan Quart. 16(3):4-15.

Marquard, R.D. 1985. Chemical growth regulation of pecan seedlings. HortScience 20:919-921.

Mika, A. 1986. Physiological responses of fruit trees to pruning. Hort. Rev. 8:337-378.

O'Barr, R.D. 1977. Nutrients: Their impact. Pecan Quart. 11(4):4-10.

Smith, M.W. and J.B. Storey. 1976. The influence of washing procedures on surface removal and leaching of certain elements from pecan leaflets. HortScience 11:50-52.

Sparks, D. and G.D. Madden. 1977. Effect of genotype on the elemental concentration of pecan leaves. HortScience 12:251-252.

Steffans, G.L. and S.Y. Wang. 1986. Biochemical and physiological alterations in apple trees caused by a gibberellin biosynthesis inhibitor, paclobutrazol. Acta Hort. 179:433-442.

Storey, J.B. and L.A. Sistrunk. 1987. Nutrition of horticultural plants laboratory manual. Texas A\&M Univ., College Station.

Wareing, P.F. and I.D.J. Philips. 1970. The control of growth and differentiation in plants. Pergamon, New York.

Wood, B.W. 1984. Influence of paclobutrazol on selected growth and chemical characteristics of young pecan seedlings. HortScience 19:837839

Wood, B.W. 1986. Influence of paclobutrazol (PP333), flurprimidol (EL-500), and ortho XE1019 (Chevron) growth retardants on growth and selected chemical and yield characteristics of Carya illinoensis. Acta Hort. 179:287-288.

Wood, B.W. 1988a. Paclobutrazol suppresses vegetative growth of large pecan trees. HortScience 23:341-343.

Wood, B.W. 1988b. Paclobutrazol suppresses shoot growth and influences nut quality and yield of young pecan trees. J. Amer. Soc. Hort. Sci. 113:374-377

Wood, B.W. 1988c. Paclobutrazol, uniconazol, and flurprimidol influence shoot growth and nut yield of young pecan trees. HortScience 23:10261028.

Worley, R.E. 1977. Progress in pruning research for large trees. Pecan South 4(4):164-166, 184.

Worley, R.E. and M. Smith. 1984. Pecan yield estimation. HortScience 19:664

Yadava, U.L. 1986. A rapid and nondestructive method to determine chlorophyll in intact leaves. HortScience 21:1449-1450. 